\title{
Çocukluk Çağı Cinsel İstismarına Yönelik Tedavi ve Önleme Yaklaşımları: Bir Gözden Geçirme*
}

\author{
Meryem Dedeler ${ }^{1}$ \\ Tuğçe Öpöz ${ }^{2}$ \\ Cansu Öztürk ${ }^{3}$
}

\begin{abstract}
ÖZ
Bu derlemenin amacı, çocuk istismarı ve ihmali hakkında genel bir bilgi vermek ve istismar ve ihmale uğramış çocuklara uygulanacak terapötik yöntemleri özetlemektir. Derlemede istismar türlerinden fiziksel, duygusal, cinsel istismar ve çocuk ihmalinin tanımları yapılmış ve istismarın çocuk üzerindeki kısa ve uzun süreli etkileri belirtilmiştir. Özellikle cinsel istismara odaklanan derlemede cinsel istismar hakkında genel bir giriş yapıldıktan sonra cinsel istismara yönelik tedavi yaklaşımları ve cinsel istismarı önleme çalışmaları özetlenmiştir. Cinsel istismara yönelik tedavi yaklaşımları genel olarak çocuğun istismara uğradığı çevreden uzaklaştırılmasını, istismar uygulayan kişiyle çocuğun ilişkisinin kesilmesini, çocuğun işlevsel olmayan inançlarıyla ve olumsuz duygularıyla başa çıkılmasını, çocuğun kendisine olan saygısının artırılmasını, değerli olduğunu hissetmesine yardımcı olunmasını kapsamaktadır. Cinsel istismarda Bilişsel- Davranışçı Terapi (BDT), oyun terapisi gibi tedavi yaklaşımları kullanılmaktadır. Ayrıca, çocuğun öyküsünü anlatmasına yardımcı olmak amacıyla çizimler, hayvan destekli terapi, kitap ve öyküler, kum havuzu gibi yöntemler kullanılmaktadır. Cinsel istismarı önleme çalışmaları ise hastanelerde Çocuk Koruma Birimlerinin oluşturulmasını, toplumun bilinçlendirilmesini, çocuğa sosyal beceri eğitimi verilmesini, çalışma kâğıtlarını ve okullarda uygulanan psiko- eğitim çalışmalarını kapsamaktadır.

Anahtar Sözcükler: Çocuk istismarı, cinsel istismar, tedavi, önleme, psiko- eğitim.
\end{abstract}

1 Ankara Üniversitesi, Dil ve Tarih- Coğrafya Fakültesi, Psikoloji Bölümü

2 Ufuk Üniversitesi, Fen Edebiyat Fakültesi, Psikoloji Bölümü

3 İlgi Otizm Özel Eğitim ve Rehabilitasyon Merkezi

İletişim: mrymddlr@gmail.com

*Bu derleme Prof. Dr. Gülsen Erden'in Çocuk Psikoterapileri dersinde ödev olarak hazırlanmış ve sunulmuştur.

Gönderim Tarihi: 7.11.2015

Kabul Tarihi: 14.01.2016 


\section{Abstract \\ A Review about Childhood Sexual Abuse Treatment and Prevention Strategies*}

This review aims to give general information about child abuse and neglect, and summarizes therapeutic methods that can be used while working with abused and neglected children. The review includes general definitions of physical, emotional, and sexual abuse, and child neglect; and their short and long term effects on the children. This review focuses on especially sexual abuse, and covers the definition of sexual abuse, its effects on the children, the therapeutic methods that can be utilized in sexual abuse, and the prevention programs. Therapeutic methods include moving the abused child away from the environment in which the sexual abuse occurred, breaking connections between the abused child and the abuser, dealing with the child's negative feelings and beliefs, increasing the child's self- respect, and helping the child feel precious. Cognitive Behavioral Therapy and Play Therapy can be used in sexual abuse. Moreover, drawings, sandbox, animal supported therapy, books and storytelling can be used in working with sexually abused children. In terms of prevention programs, child protective units should be established in the hospitals. The society should be informed about the sexual abuse with brochures, campaigns etc. Furthermore, social skills training should be provided to the victim. The work sheets and psycho-educative activities in the schools could also be helpful.

Keywords: Child abuse, sexual abuse, treatment, prevention, psychoeducation.

* This review was prepared and presented as an assignment in "Child Psychotherapies" course given by Prof. Dr. Gülsen Erden 


\section{Çocukluk Çağı Cinsel İstismarına Yönelik Tedavi ve Önleme Yaklaşımları: Bir Gözden Geçirme}

Çocuk istismarı; toplumca koyulmuş kurallara uygun olmayan ve konuyla ilgili uzmanlara göre uygunsuz ve zarar verici olarak tanımlanmış davranışların anne- baba ya da bakım veren başka bir yetişkin tarafından çocuğa uygulanması ve bu eylem ve eylemsizliklerin tümünün çocuğun gelişimini olumsuz yönde etkilemesi olarak tanımlanmaktadır. Çocukluk çağı istismarı ve ihmali, çocuğun psikolojik, fizyolojik, cinsel ya da sosyal açıdan zarar görmesine neden olabilmekte ve çocuğun sağlığını ve güvenliğini tehlikeye sokmaktadır (Taner ve Gökler, 2004). Yılmaz, İşiten, Ertan ve Öner (2003) ve Johnson (2003) çocuk istismarının tek seferle sınırlı kalmayabileceğini, aksine tekrarlanabilir olduğunu, istismarın çocuğun yakın çevresinden gelebileceğini ve çocuk üzerinde uzun süreli etkilere yol açarak çocuğun travma yaşamasına sebep olabileceğini ifade etmektedirler.

İstismarın sebeplerine bakıldığında, istismar; ebeveynlerin bireysel özellikleri, toplumsal problemler, aile içindeki iletişim eksikliği ve çocuğun gelişiminden kaynaklanan sıkıntılarla ilgili olarak yaşanabilmektedir (Kara, Biçer ve Gökalp, 2004). Bir çocuğun istismar edilmesindeki sebepler iç ve diş faktörler olarak sınıflandırılabilir (Bahar, Savaş ve Bahar, 2009). Yoksulluk düzeyinin yüksek olması, sosyal destek kaynaklarının yetersiz olması, suç oranının yüksek olduğu bir çevrede ikamet etmek, işsizlik, sosyal hizmetlerin yetersiz olması gibi faktörler dış kaynakları oluştururken; anne ve babanın boşanması, ebeveynlik becerilerinin zayıf olması, ebeveynlerin dürtü kontrollerinin düşük olması, aile içindeki fiziksel ve psikiyatrik rahatsızlıklar, anne babanın stresle baş etme ve problem çözme becerilerinin düşük olması, madde kullanımı, aile içi ilişkilerdeki bozulmalar, çocuktaki davranış problemleri, çocuktaki gelişimsel ve fiziksel problemler ise iç faktörleri oluşturmaktadır (Sattler, 1998; Bahar ve diğerleri, 2009).

\section{Çocuk İstismarı Türleri}

Çocuk istismar1; fiziksel istismar, duygusal istismar, cinsel istismar ve ihmal olmak üzere dört ana grupta incelenmektedir. $\mathrm{Bu}$ istismar türlerinden her biri tek başına gerçekleşiyor olabileceği gibi, bu türlerden bir kaçının aynı anda çocuğa uygulanıyor olma ihtimali de vardır. Örneğin, fiziksel istismar, cinsel istismar ve ihmalin bulunduğu durumlarda, duygusal istismar da genellikle bunlara eşlik etmektedir (Sattler, 1998).

Çocuk istismarı türlerinden tespiti en kolay olanı fiziksel istismardır (Bahar ve diğerleri, 2009). Fiziksel istismar, çocuğun kaza dışı nedenlerle yaralanmasını ya da ailesi tarafindan yeterince gözetilmemesine bağlı olarak yaşadığı kazaları kapsamaktadır (Kara ve diğerleri, 2004). Bir başka deyişle, fiziksel istismar çocuğa vurma, tekme atma; çocuğu itme, sarsma, 1sırma, dövme, yakma, zehirleme gibi fiziksel olarak zarar verici davranışların çocuğun sağlığını, yaşamını, gelişimini ve onurunu tehlikeye sokacak biçimde kasıtlı olarak gerçekleştirilmesidir (Pala, Ünalacak ve Ünlüoğlu, 2011). Fiziksel istismar sonucu çocukta görülen yaralanmalar tek bir fiziksel istismarın sonucu olabileceği gibi, seri bir şekilde art arda gerçekleşen istismar eylemlerinin sonucu da olabilmektedir (Sattler, 1998). Fiziksel istismar gören çocuklar tehlike işaretlerine karşı sürekli tetikte olma, huzursuzluk, s1k s1k travmatik anıya geri dönüş, karanlıktan, ebeveynlerden ve eve gitmekten korkma, genel olarak yetişkinlerle fiziksel temastan ve onlarla yalnız kalmaktan kaçınma gibi kaygı belirtileri ve depresyon, diğerlerine karşı güven kaybı, çevredeki kişilerden kopma (Sattler, 1998), sosyal ilişkilerden geri çekilme (Sanders ve Brown, 2007) gibi içe çekilme belirtileri göstermektedir ve bu çocukların benlik saygıları olumsuz yönde etkilenmektedir (Güner, Güner ve Şahan, 2010). Çocukta fiziksel istismar sonucunda, saldırganlık, agresyon, akranlarına karşı tahrik edici davranışlar, iştah durumunda değişiklikler, regresyon, kendisinden küçük kardeşlerine karşı koruyucu tutum gibi çeşitli psikolojik ve davranışsal değişimler gözlenebileceği gibi (Sattler, 1998; Sanders ve Brown, 2007); okul performansında düşüş gibi akademik alanda başarısızlıklar ve bilişsel alanda yetersizlikler de 
görülebilmektedir (Hildyard ve Wolfe, 2002).

Diğer bir istismar türü olan duygusal istismar ise, çocuğun duygusal gelişimini ve benlik saygısını olumsuz yönde etkileyen (Al-Qaisy, 2007) ve süreklilik gösteren (Sattler, 1998) bir davranış örüntüsüdür. Duygusal istismar ve ihmal, çocuğun ya anne-babasından ya da kendisine bakımveren kişiler tarafından gerçekleştirilmektedir. Duygusal istismar ve ihmalin olduğu ailelerde ya anne babanın her ikisi de bu duruma katkıda bulunmakta ya da biri çocuğa kötü davranırken diğeri etkisiz kalmaktadır (Mullen, Martin, Anderson, Romans ve Herbison, 1996). Duygusal istismar, çocuğu küçümseyici ifadeleri, sürekli eleştirmeyi, aşağılamayı, yalnız bırakmayı, başkalarıyla karşılaştırmayı, aile içi uyuşmazlıklarda taraf olmaya zorlamayı, aşırı korumayı; çocuğa lakap takmayı, hakaret etmeyi, bağırmayı, sevgi ve ilgi göstermemeyi, duygusal destek sağlamamayı, çocuğun yaşına ve özelliklerine uygun olmayan beklentilerde bulunmayı içermektedir (Sattler, 1998; Glaser, 2002; Güner ve diğerleri, 2010). Ebeveynlerin bu tutumları sonucunda duygusal istismarın etkileri çocuklarda gerginlik, aileden uzaklaşma, bağımlı kişilik, değersizlik duyguları, uyumsuzluk ve saldırgan davranışlar şeklinde gözlenebilmektedir (Kara ve diğerleri, 2004). Duygusal istismarın sonuçlarına daha uzun bir süreç içerisinde bakıldığında duygusal istismara maruz kalan bireylerde; yetişkinlikte düşük öz güven, depresyon ve intihar davranışı gibi psikolojik sorunların görülebileceği ortaya konulmuştur. (Mullen ve diğerleri, 1996).

Duygusal istismar diğer istismar türlerine göre en çok rastlanılan istismar türü olmasına rağmen (Al- Qaisy, 2007; Sorbo, Grimstad, Bjorngaard, Schei ve Lukasse, 2013) fark edilmesi ve tanınmas1 konusundaki sorunlardan dolayı tespiti oldukça zor olmaktadır (Glaser, 2002). Bu bağlamda, Ahioğlu (2004) alanyazındaki çalışmaları ve yargı kararlarını incelediği çocuk istismarı ile ilgili çalışmasında; duygusal istismara göre cinsel ve fiziksel istismarın görsel açıdan daha somut sonuçlarının olması, bu iki istismar türünün olumsuz sonuçlarının duygusal istismara göre daha fazla olduğu yönünde toplumdaki yaygın yanlış inanç, medyanın cinsel ve fiziksel istismara duygusal istismardan daha çok yer vermesi, kültürel olarak istismarın gizli tutulması ve adli kaynaklardaki düzensizliklerden dolayı vakaların istatistiklere yansımaması nedenlerinden dolayı duygusal istismarın tespitinin ülkemizde zorlaştığını belirtmektedir.

Fiziksel ve duygusal istismarın yanı sıra, ihmal kavramı da çocuk istismarı literatüründe önemli yer tutmaktadır. İhmal kavramının tanımlanması oldukça zordur çünkü kişiden kişiye, kültürden kültüre değişiklik göstermektedir (WHO, 2002). Çocuk ihmali, çocuğa bakma sorumluluğunu üstlenen kişilerin yapmaları gerekenleri yerine getirmemesi şeklinde tanımlanabilmekte ve çocuğun beslenme, barınma, giyim, hijyen gibi ihtiyaçlarının karşılanmaması gibi davranışlarla gözlenmektedir (Yaşar ve Akduman, 2007). İhmal duygusal boyutta olduğu gibi fiziksel şekilde de gözlenebilmektedir. Çocuğun ilgi, sevgi ve duygusal güvenlik gibi psikolojik ihtiyaçlarına cevap vermedeki başarısızlık, duygusal yoksunluk ve psikolojik olarak ulaşılmazlık, çocuğun yanında diğer aile bireylerine yönelik şiddet davranışları gösterme, çocuğun madde kullanımı gibi yasal olmayan faaliyetlerine izin verme ve bunlara karşı çocuğu cesaretlendirme ihmalin duygusal boyutunu oluştururken; çocuğun sağlıkla ilgili ihtiyaçlarını karşılamayı reddetme ya da erteleme, çocuğu terk etme, yetersiz gözetim, çocuğu madde kullanımına pasif olarak maruz bırakma, yetersiz gözetim sonucunda çocuğun kazara ilaç yutmasına neden olma ise ihmalin fiziksel boyutunu oluşturmaktadır (Sattler, 1998).

Çocuk ihmali erken yaşlarda başlamakta ve çocuğun gelişimsel olarak bir takım sorunlar yaşamasına sebep olabilmektedir. Bazı durumlarda ihmal erken çocukluk döneminden ergenliğe kadar devam edebilmektedir (Hildyard ve Wolfe, 2002). İhmalin etkileri çocuk üzerinde bu kadar uzun süreli ve önemli olmasına rağmen anne-babaların ihmal ve istismarın sınırlarını tam olarak bilmedikleri görülmektedir.

Örneğin, Keser, Odabaş ve Elibüyük (2010) tarafından anne babaların çocuk istismarı ve ihmali konusunda bilgi düzeylerinin incelendiği araştırmada; çocuğun anne babası tarafından aşağılanmasını haklı buldukları, anne-babaların bazı çocukların dayağı hak ettiklerini düşündüğü gibi sonuçlara ulaşılmıştır. Bu araştırma anne babaların bu konu hakkındaki yanlış tutumlarını göstermektedir. 
İstismarın önemli çeşitlerinden biri de cinsel istismardır ve tespiti oldukça zor olmaktadır (Kara ve diğerleri, 2004). Cinsel istismar, çocuğa yapılan herhangi bir cinsel yaklaşımı, cinsel içerikli bir eylemi; okşamaktan zorla cinsel ilişkiye kadar uzanan tüm cinsel eylemleri içermektedir (Topçu, 2009). Cinsel istismar; genital bölgeleri elleme, teşhircilik, röntgencilik (Yaşar ve Akduman, 2007), çocuk ve yetişkin arasında mastürbasyon, vajinal ya da anal penetrasyon, çocuğa pornografik materyallerin gösterilmesi ya da pornografik materyallerde çocukların kullanılması (Sattler, 1998) gibi davranışları kapsamaktadır.

Diğer istismar türlerinde olduğu gibi cinsel istismar da genellikle çocuğun yakın çevresinden biri tarafından gerçekleştirilebilmektedir (Bahar ve diğerleri, 2009). İmren, Ayaz, Yusufoğlu ve Arman (2013) çalışmalarında istismarcının çocuğun yakın çevresinden biri olduğu, özellikle 6 yaş altında istismara uğrayan çocukların tamamının aile bireylerinden birinin veya tanıdıkları bir ergenin tacizine uğradığını göstermişlerdir. Cinsel istismarın ardından istismara uğramış çocuk ve ergenlerin çoğunda ruhsal bozukluklar gözlenebilmekte; anksiyete, depresyon, somatizasyon bozuklukları gibi psikolojik sorunlar ortaya çıkabilmektedir (Paolucci, Genius ve Violato, 2001). Benzer şekilde çocuklardaki cinsel yollarla bulaşan hastalıkların varlığı, genital bölgelerdeki problemler (Yaşar ve Akduman, 2007), kaygı, yoğunlaşma problemleri, öfke, ebeveynlerden korkma, eve gitmekten korkma, güven kaybı, düşük benlik saygısı, utanç, kendini suçlama gibi belirtiler cinsel istismarın işaretleri olabilmektedir (Sattler, 1998).

Cinsel istismarın fiziksel ve psikolojik belirtileriyle beraber, cinsel tacize uğramış çocukların genellikle bir başka bireye açılmakta çekingen kalabildiği, kendileri yerine bir başka çocuktan söz edebildiği görülmektedir. Çocuktaki davranış değişikliği tacizin ifade şekli olabilmektedir (Ovayolu, Uçan ve Serindağ, 2007). Ekşi'ye (1999) göre, 0-3 yaş arası çocuklarda yeme ve uyku bozuklukları, yabancılardan korkma ve yaşına uygun olmayan cinsel oyunlar gözlemlenebilmektedir. Benzer şekilde 3-6 yaş arası çocuklarda bebek gibi konuşma, içe çekilme, birine yapışır gibi bağlanma, yeme ve uyku bozukları, sinirlilik, boyun eğme davranışı, sık ve süreğen cinsel oyun, mastürbasyon gibi yaşanan travma ile ilişkili belirtiler görülebilmektedir. Gözlemlenen travma ile ilişkili bu belirtilerin düzeyi bazı faktörlere bağlı olarak değişebilmektedir. Çocukla saldırgan arasındaki yaş farkının fazla olması, saldırganın tanıdık ya da aileden biri olması, istismar sırasında şiddet ve zor kullanılması ve istismarın süreğen bir şekilde devam etmesi yaşanan belirtilerin daha ciddi olmasına neden olabilmektedir (Avcı ve Tahiroğlu, 2006).

$\mathrm{Bu}$ derlemede özellikle cinsel istismar üzerinde durulmuş, cinsel istismara yönelik tedavi yaklaşımları ve cinsel istismarı önleme çalışmaları vurgulanmıştır.

\section{Cinsel İstismara Yönelik Tedavi Yaklaşımları}

Cinsel istismar ortaya çıktıktan sonra yapılacak ilk iş, çocuğu istismara uğradığı çevreden uzaklaştırmaktır. Çocuğa istismarda bulunan kişiyle çocuğun ilişkisi hemen kesilmelidir. Tedavide aile bütünlüğünü korumak, çocuğu aile ortamından ayırmadan tedaviyi sürdürmek temel yaklaşım olsa da aile içi istismar olgularında bu her zaman mümkün olmamaktadır (Avcı ve Tahiroğlu, 2006). İstismara uğramış çocukların tedavisinde bireysel farklılıklar göz önüne alınarak tedavi planı yapılmalıdır. Cinsel istismarın tedavisinde izlenecek ilk ve temel aşama istismara uğrayan kişiye inanmaktır. İstismara uğrayan kişi tedavi süresince kendisine inanıldığını, güvende olduğunu ve yardım için kendisini dinleyen, güvenilen ve anlayan birisinin olduğunu bilmelidir (Topçu, 2009). Cinsel istismara uğrayan kişiler uğradıkları mağduriyetin kalıcı olmadığına inandırılmalı ve kendilerine saygın, sevgiye layık ve değerli oldukları duygusunu geliştirebilmeleri için yardım edilmelidir (Topçu, 2009). Bunun için terapist öncelikle çocukla güven ilişkisi kurarken yönlendirici bir tarz yerine çocuk merkezli bir tarzı benimsemelidir. Terapist çocuğun vereceği anlayış, yol gösterme, onama ve kontrol ihtiyacı işaretlerine duyarlı olmalı ve bunlara uygun bir şekilde cevap vermelidir (Sanders ve Brown, 2007). Terapistin güven verici bu tutumu çocuğun istismar yaşantısını anlatmasını kolaylaştırmakta ve çocuğun duygularının farkında olmasına ve duygularını ifade edebilmesine yardımcı 
olabilmektedir. Güven ilişkisinin kurulamamasından kaynaklanabilecek dirence karşı terapist dikkatli olmalı, çocuğun yaşadıklarıyla empati kurmalı, kendi duygularının da farkında olmalıdır (Özen, 2015). Çocukla güven ilişkisi kurulduktan ve terapi için uygun koşullar hazırlandıktan sonra cinsel istismar tedavisinde pek çok teknik kullanılabilmektedir.

Tedavide bireysel ve grup terapileri, oyun terapisi, aile terapisi ve ilaç tedavileri kullanılabilmektedir (Avcı ve Tahiroğlu, 2006). Özellikle, Bilişsel Davranışçı Terapi (BDT) cinsel istismara uğrayan bireylerde etkili olabilmekte ve bu bireylerin yapmış olduğu otomatik düşünce hatalarını ve bilişsel çarpıtmaları alternatifleriyle değiştirebilmektedir (Topçu, 2009). İstismar sonucunda çocukta kuşku, reddetme, iğrenme, güvensizlik gibi duygular ve işlevsel olmayan inançlar oluşabilmektedir (Avc1 ve Tahiroğlu, 2006). Buna göre çocuk yaşadığ 1 travma sonucunda hiçbir şeyin eskisi gibi olmayacağına ve olanların telafisinin olmadığına inanabilmektedir. $\mathrm{Bu}$, çocuğun, travmayı arkasında bırakmasını engelleyebileceğinden, bu tür inançlarla terapi ortamında başa çıkmak gerekmektedir (Geldard ve Geldard, çev., 2013). Yanlış inançlarla çalışırken terapist, öncelikle fark ettiği bu yanlış inançları çocuğa yansıtmalı; sonra da çocuğun bu yanlış inançların doğru olup olmadığını sınamasını sağlamalıdır. Bunun için de, çocuğun sahip olduğu yıkıcı inançların ne kadarının kendi deneyimi ne kadarının kendisine söylenenler sonucu oluştuğunun belirlenmesi gerekir. Tüm bunların ışı̆̆ında da terapist çocuğun düşüncesinin altında yatan mantığı sorgulamalı, çocuğun daha farklı inançları gözden geçirmesine ve yanlış inançları daha uygun inançlarla değiştirmesine yardımcı olmalıdır (Geldard ve Geldard, çev., 2013). Bu bağlamda, İran'da cinsel istismara uğrayan 12-13 yaşlarındaki kız çocuklarına yönelik yapılan 12 seanslık Göz Hareketleriyle Duyarsızlaştırma ve Yeniden İşleme (Eye Movement Desensitization and Reprocessing-EMDR) ve Bilişsel Davranışçı Terapi uygulama sonuçlarına göre her iki terapi yöntemi de çocukların stres belirtilerini düşürmede ve olumlu davranışlarını artırmada etkili olmuştur. Sonuçlara göre EMDR, BDT'den daha etkili bulunmuştur (Jaberghaderi, Greenwald, Rubin, Zand ve Dolatabadi, 2004).

Tedaviye yönelik yapılabileceklerin uygun bir biçimde değerlendirilmesi gerekmektedir. Çocukla yapılan terapide çocuğun öyküsünü anlatmasına yardımcı olmak, güçlü duygularını yaşayabilmesi, zor ve acı olsa da yaşadıklarını anlatabilmesi için ortam sağlamak ve terapötik değişime yardımcı olmak gerekir. Bunun için de çeşitli terapi becerileri ve yaklaşımlar kullanılabilir (Geldard ve Geldard, çev., 2013). Bu yaklaşımlar oyun terapisi, çizim yapma, boyama-kolaj ve yapılandırma, hayvan destekli terapi, kitap ve öykü kullanımını kapsamaktadır.

\section{Oyun Terapisi}

Nasıl yetişkinler düşünce ve hislerini kelimelerle anlatıyorsa çocuklar da içlerindeki duygu ve düşünceleri oyunla dışa vurmaktadırlar (Axline, 1981). Bu bağlamda oyun terapisi cinsel istismara uğramış çocuklarda da kullanılmaktadır. İstismara uğramış çocuklarda oyun terapisi genellikle 18 ay ile 2 yıl aralığında sürmektedir (Sanders ve Brown, 2007). Alanyazında bu konuda yapılmış çalışmalardan örnekler aşağıda yer almaktadır.

Reyes ve Asbrand (2005) çalışmalarında oyun terapisini cinsel istismara uğramış çocuklarda kullanmışlar ve bunun için özel oyun odaları düzenlemişlerdir. Bu oyun odaları minyatür figürleri, kuklaları, sanatla ilgili araç gereçleri, oyuncak bebekleri, mobilya içeren oyuncak bebek evlerini, kitapları ve masa oyunlarını içermektedir. Çalışma boyunca her bir katılımcı haftalık 50 dakikadan oluşan bireysel oyun terapisi oturumlarına katılmış, aile terapisi almış ve bazı aileler anne babalık sınıflarına katılmışlardır. $\mathrm{Bu}$ çocuklara çalışmanın başında ve sonunda Çocuklar İçin Travma Belirtileri Kontrol Listesi (Trauma Symptom Checklist for Children) uygulanmıştır. Bu ölçme arac1 1996 yılında Briere tarafindan geliştirilmiştir ve çocukların kendi beyanlarına dayanmaktadır. Çalışmada uygulanan oyun terapisinin cinsel istismara müdahalede etkili olduğu bulunmuştur. Buna göre, 9 aylık oyun terapisi sonucunda travma 
belirtilerinin düzeyinde, anksiyete, depresyon, travma sonrası stres puanlarında düşüş olduğu bulunmuştur (Reyes ve Asbrand, 2005).

Oyun terapisi sırasında yapılan gözlemler sonucunda cinsel istismara uğramış çocukların sergilediği bazı davranışlar görülmüştür (Homeyer \& Landreth, 1998). Örneğin, Homeyer ve Landreth'in 1998'de yaptıkları bir çalışma cinsel istismara uğramış çocukların oyun terapisi sırasında gösterdikleri davranışları belirlemeye yöneliktir. Buna göre, oyun biçimleri (saldırgan, bakım veren, regresif, cinsel, temizlenen, çatışan, ayrışmış ve kategorize edilmeyen) ve oyun çeşitleri (oyuncak, kum havuzu, resim, etkileşimli oyun ve sözelleştirme) belirlenmiştir. Olası davranışlar 178 uzman tarafından listelenmiştir. Çalışma 3-10 yaş arası 423 çocukla gerçekleştirilmiş ve alanda deneyimli 30 terapist ile yürütülmüştür. Sonuçlara göre 3-6 yaş grubu erkek çocuklar geniş açılmış ağızlar çizerken, kız çocuklar geniş açılmış ağızların içine bir takım nesneler yerleştirmiş ve kuklaları öpüştürmüştür. Yaşı daha büyük çocuklar ise oyun sırasında bakım verici tutumlar sergilemişlerdir. Çocukların yaş grupları önemli bir faktördür ancak bir diğer önemli konu da seçilecek oyuncakların niteliğidir. Uygulanacak oyun terapisinde istismara özgü oyuncaklar seçilebilir. Örneğin, Sanders ve Brown'a (2007) göre şiddete tanık olmuş çocuklarla çalışırken oyuncak silahlar kullanılabilir. Benzer şekilde, yetersiz bakım ve beslenme nedeniyle yeterince gelişmemiş çocuklarda tencere, tava, çatal, bıçak gibi oyuncaklar kullanılabilir.

Cinsel istismara uğrayan çocuklarla çalışırken oyun terapisi kapsamında kullanılabilecek bir yöntem de kum havuzudur. Genel kullanımda kum havuzu uygulaması, çocuk için çeşitli anlam ifade edebilecek ufak nesneler (oyuncak hayvanlar, figürler, küçük oyuncaklar, genel nesneler vb.) de dâhil edilerek yapılır. Bu çalışma çocuğun öyküsünü aktarmasına yardımcı olur. Çocuklar öykülerini aktarırken geçmişi ve şimdiyi yansıtabilir. Kullandığı nesnelerle ve oluşturduğu hikâyeyle kendini ortaya koyar. Çocuk kendi dünyasını yaratırken terapist onu dikkatli bir şekilde gözlemlemelidir (Geldard ve Geldard, çev., 2013).

Grubbs (1995), kum havuzu çalışmasını, çocuğun gelişimsel konuları tamamlamasına yardımcı olan, bastırılmış duygularını ve derine gömülmüş travmalarının açığa çıkmasını sağlayan bir süreç olarak ifade etmiştir. Grubbs'a göre (1995) istismara uğrayan çocukların kum havuzu çalışmalarıyla uğramayan çocukların kum havuzu çalışmaları farklılık göstermektedir. Yaptığı çalışmada, istismara uğramış ve uğramamış çocukların kum havuzu çalışmalarını karşılaştıran Grubbs (1995), öncelikle iki grup arasında insan ve hayvan figürlerini yapılandırma ve kullanmada temel farklılıklardan bahsetmiştir. Buna göre; istismara uğramamış çocuklar aileyi ya da toplumu içeren sahneleri olumlu, uyumlu ve yaşamı destekleyici olarak betimlerken; istismara uğramış çocuklar bu alanları, kolayca incinebilir mağdurlara şiddetin yöneltildiği ve kendine zarar verme davranışları içeren izole ve savaştan kalma yerler olarak betimlemişlerdir. Yine aynı çalışmada, çocukların konuları ve çevresel bağlamları ele alış biçimleri karşılaştırıldığında, istismara uğramış erkek çocuklarının şeytani ve ölümle ilişkili öğeler içeren, savaşın olduğu boş bir dünya betimledikleri görülmektedir. Oysa istismara uğramamış çocukların aileyi, toplumu, doğayı ve efsanevi yerleri içinde avlanmanın, yemek toplamanın, doğal ve ruhani hayat mücadelelerinin, evliliklerin yaşandığı bir dünya olarak betimledikleri görülmektedir.

Benzer şekilde, Zinni (1997), 10 ve 11 yaşlarındaki 52 çocuk üzerinde kum havuzu kullanarak yaptığı çalışmada, çocukları klinik grup ve kontrol grubu olarak ikiye ayırmış ve her iki gruba da eşit sayıda dağıtım yapmıştır. Klinik grup duygusal, fiziksel, cinsel istismara uğramış, ihmal edilmiş veya anne babası boşanmış, yakın bir tanıdığını kaybetmiş çocuklardan oluşurken; kontrol grubundaki çocuklar ise fiziksel ve psikolojik olarak sağlıklı çocuklardan oluşmaktadır. Ayrıca ailelere Achenbach Çocuk Davranışları Kontrol Listesi verilmiş; bundan elde edilen puanlara göre her iki gruptaki çocuklar da kesme puanı dikkate alınarak sosyal yeterlik ve çocuğun yaşadığı problemlere göre düşük/ yüksek yeterlik ve düşük/yüksek problem olmak üzere farklı kategorilerde değerlendirilmiştir. Çocuklara çalışmada kum havuzu gösterilmiş; onlardan kum havuzunu ve minyatür figürleri kullanarak bir resim yaratmaları; resim tamamlandıktan sonra ise bu resme bir başlık bulmaları istenmiştir. Değerlendirmeler içerik, tema ve kum havuzunun kullanımı 
olmak üzere 3 alanda yapılmıştır. İçerik açısından bakıldığında, klinik gruptaki çocuklar, resimlerinde daha çok kuşlar, kelebekler, evler, bayraklar, işaretler ve tatil öğeleri kullanırken; kontrol grubundaki çocuklar daha çok çubukları ve botları kullanmıştır. Klinik gruptaki çocuklar kontrol grubuna göre daha fazla sayıda nesne kullansa da bu nesnelerin başlıkla ve anlatılan hikâye ile uyumsuz olduğu gözlemlenmiş ve bunun çocukların düzensiz dünyalarını temsil ettiği düşünülmüştür. Ayrıca klinik gruptaki çocukların tatil öğesi kullanmaları araştırmacılar tarafından bu çocukların bir fantezi dünyası yaratma ihtiyacı duydukları şeklinde; işaretleri kullanmaları ise diğerlerine karşı "girilmez" ve "dur" demek için bir sınır yaratma ihtiyacı olarak yorumlanmıştır. Kum havuzunun kullanımı açısından bakıldığında kontrol grubundaki çocuklar oyunları sırasında kum havuzunun sınırları içerisinde kalırken; klinik gruptaki çocuklar sınırların dışına çıkmıştır. Son olarak kontrol grubundaki çocuklar daha düzenli ve organize resimler yaratırken; klinik gruptaki çocukların resimlerinin düzensiz olduğu ve bu çocukların odaklanma sorunu yaşadıkları görülmüştür. Bu çalışma sonucunda çocukların kendilerini sözel olarak ifade edemeseler de yaptıkları kum havuzu faaliyeti sayesinde iç dünyalarını diğer insanlara aktarabildikleri görülmüştür. Bu da kum havuzunun hem bir değerlendirme hem de tedavi yöntemi olarak kullanılabileceğini göstermektedir (Zinni, 1997).

\section{Çizim Yapma, Boyama, Kolaj ve Yapılandırma}

Terapi sırasında çizim, boyama, kolaj ve yapılandırma yöntemlerinden yararlanılabilmektedir. Çizim, boyama, kolaj ve yapılandırma etkinliklerinde çocuk; kendi öyküsünü veya öyküsünün bir kısmını, ifade edip anlamlandırabilmekte, aynı zamanda duygularını isimlendirip ifade edebilmekte, duygularını yaşayabilmekte ve onlarla başa çıkabilmektedir (Geldard ve Geldard, çev., 2013). Çocuk resmini tamamladıktan sonra terapist, çocuğun çizdiği resmin anlamı hakkında konuşmak için geri bildirim cümleleri kullanabilir ve yansıtmalar yapabilir (Geldard ve Geldard, çev., 2013). Çocukların çizimlerinde yaşantılarını aktardıkları düşünülmektedir.

Renvoize'ye (1993) göre cinsel istismara uğrayan çocukların resimlerinde cinsel organları tasvir eden çizimler yaptıkları, beden algısı bozuk insan figürleri çizdikleri, insan figürlerine cinsel organlar ekledikleri gözlenmektedir. Aynı şekilde istismar mağduru bu çocuklar, vücudunun bir kısmı ya da yüzü çarpıtılmış, deforme olmuş, gölgelenmiş ve karalanmış resimler çizmektedirler. Ayrıca ağzı ve kolları olmayan resimler veya vücuttaki herhangi bir bölgenin özel olarak vurgulandığı resimler bu çocukların çizimlerinde gözlenmektedir (Renvoize'den aktaran Bulut, 2008).

Katz, Barnetz ve Hershkowitz tarafından 2005 ve 2007 yılları arası gerçekleştirilen çalışmada cinsel istismara uğramış 4- 14 yaş arası 125 çocuk alınmış, bu çocuklarla ön görüşme yapılmış ve ardından çocuklar seçkisiz olarak deney ve kontrol gruplarına atanmışlardır. Çizim grubunda çocuklardan kendilerine ne olduğunu çizmeleri istenmiştir. Daha sonra görüşmeci çocuklara çizim öncesinde yaptıkları görüşmeyi ve çizimini de dikkate alarak olan bitenleri başından sonuna kadar anlatmalarını istemiştir. Kontrol grubunda ise çocukların oyun oynamasına izin verilmiş ancak herhangi bir çizim yapmalarına imkân tanınmamıştır. Uygulama sonucunda ise çocuklara kendilerini görüşme öncesinde, görüşme sirasında ve görüşme bittiğinde nasıl hissettikleri sorulmuştur. Sonuçlara göre, çizim yapan grup uygulama sırasında daha olumlu şeyler hissettiğini söylerken, negatif hisler konusunda bir farklılaşma bulunmamıştır. Aynı şekilde uygulama sonrası hislerinde de çizim yapan ve yapmayan grup arası bir farklılaşma ortaya çıkmamıştır. Bu çalışmanın bulgularına göre yapılan çizimler çocukların güven, özdeğer ve adalet duygusunu güçlendirdiği için uygulayıcılar açısından işlevsel bir öneme sahiptir (Katz, Barnetz ve Hershkowitz, 2014). 


\section{Hayvan Destekli Terapi}

İstismara uğramış çocukların tedavisinde kullanılan bir diğer yöntem de hayvan destekli terapilerdir. Hayvan destekli terapiler çocukların duygusal mekanizmasını ve bilişlerini etkilerken, bir yandan da çocuklara oyun oynamayı öğretir. Aynı zamanda fiziksel ve psikosomatik açıdan da önemli bir yere sahiptir (Ballarini, 2003). Hayvanlar çocukların kendilerini ortaya koyabilmelerini sağlamaktadır (Reichert, 1998). Hayvan destekli terapi; terapist ve çocuk, terapist ve hayvan, çocuk ve hayvan, hayvan ve hayvan arasındaki duygusal bağa ve ilişkiye dayanmaktadır. Çocuk terapi süresince aktif bir katılımcı ya da gözlemci olabilmektedir. Terapide terapist; çocuk ile hayvan ve çocuk ile çocuğun farkındalık, içgörü kazanmasını sağlayan ve kendini yansıtmasına yardımcı olan içsel süreçleri arasında köprü görevi görmektedir. Bu terapide hayvan araç çocuk ise terapinin odak noktasıdır. Terapi boyunca terapist çocukla bilişsel, sosyal, davranışsal ve duygusal düzeylerde çalışmakta ve sağlıklı bir duygusal gelişim hedeflemektedir (ParishPlass, 2008).

Parish-Plass 2008 'de yaptığı bir çalışmada istismara uğrayan çocuklara hayvan destekli terapi yöntemi uygulamıştır. Bu yönteme göre istismara uğrayan çocukların travmatik meselelerle baş etmesinde hayvanların varlığı yatıştırıcı ve daha az tehdit edici bir ortam sağlamıştır. Bu çalışmada çocukların hayvanları incitmemesi adına gerekli önlemler alınarak onlarla oyun odasında ve hayvanat bahçesinde temas etmeleri sağlanmıştır. Yapılan gözlemlerde çocukların hayvanlara karşı bakım veren, ihmal eden ya da istismar eden bir rol benimsedikleri görülmüştür. Araştırmacıya göre çocukların bu rolü benimsemesinde ebeveyn çocuk arasındaki ilişkinin etkili olabileceği düşünülmüştür. Uygulama sonunda çocuklardan bazılarında içsel çalışma modellerinin, benlik algısının değiştiği ve empati becerisinin geliştiği gözlemlenmiştir. Ayrıca bu çalışmada çocukların daha uygun anne- çocuk etkileşimini keşfetme firsatları olmuştur.

\section{Kitap ve Öykü Kullanımı}

Kitap ve öyküler cinsel istismarda eğitici amaçlarla ve çocuğun kendini dışa vurmasını kolaylaştırabilmek amacıyla kullanılmaktadır. Öyküler, çocuğun kendi korku ve sıkıntısını öyküdeki bir karakter veya durumla özdeşleştirerek tanımasına yardım etmektedir. Çocuk, öyküdeki karakter sayesinde başına gelen olayı bir başkasının da yaşayabileceğini görmüş olmaktadır. Öyküler, problemleri üzerinde düşünmek ve farklı çözüm yollarını keşfetmek konusunda çocuğa yardım etmektedir. Çocuk öyküler yardımıyla bazı olayların önlenemez olduğunu öğrenmektedir (Geldard ve Geldard, çev., 2013).

Benzer şekilde Herman (1997) yaptığı çalışmada, öykü anlatımının ve öyküde yer alan olayları terapistle birlikte canlandırmanın çocuğu kaygı yaratan durumdan uzaklaştırdığını, çocuğun cinsel istismarla ilgili verdiği tepkileri ve düşünceleri araştırma fırsatı tanıdığını ifade etmektedir. Bu öykü ve canlandırmalar, çocuğun yaşadığı istismarla ilgili birçok şeyi yansıtmasını sağlamaktadır (Herman, 1997). Renvoize'ye (1993) göre, istismara uğrayan çocukların öykülerinde genellikle gizlilik içeren konular, gizlilik için özel bir istek, karakterler için ayrı yatak odaları belirlemeleri ve koruyucu anne baba temaları bulunmaktadır (aktaran Bulut, 2008).

Bu verilerin 1şı̆̆ında, çocuk istismar ve ihmalinin tedavisinde bahsedilen yaratıcı yöntemlerin işlevsel olarak kullanılabileceği söylenebilir. Ancak istismar ve ihmal konusunda tedavi yaklaşımlarının yanısıra bir diğer önemli konu da önleme çalışmalarıdır. 


\section{İstismarda Önleme Çalışmaları}

İstismarla ilgili yapılan önleme çalışmalarında en üst düzey amaç, çocuk istismarını başlamadan durdurmaktır (Centers for Disease Control and Prevention [CDC], 2014). Bunun için tüm çocuklara yönelik koruma programları yapılmalıdır (Acehan ve diğerleri, 2013). Önlemeye yönelik geliştirilecek stratejiler aileleri desteklemeli, anne babaya olumlu anne babalık becerileri, iletişim becerileri, uygun disiplin yaklaşımları ve çocuğun fiziksel ve duygusal ihtiyaçlarını nasıl karşılayacakları öğretilmelidir (Centers for Disease Control and Prevention [CDC], 2014).

Çocuk istismarı vakalarının tanınmasında ve önlenmesinde en uygun yaklaşım ekip çalışmasıyla sağlanabilir. Amerika Birleşik Devletleri'nde istismarı önleme çalışmaları, okul programları, kitaplar, broşürler, filmler, dergiler, TV programları, tiyatrolar ve okullarda verilen dersler aracılığıyla sağlanmaktadır. Bu programlar çocuklara, anne babaya ve çocuklarla çalışan meslek gruplarına verilmektedir (Topçu, 2009). Ayrıca çocukların karşılaştıkları kötü durumlarla başedebilmelerini sağlamak için onlara bilişsel yetenekler ve sosyal beceriler kazandırmak amaçlanmaktadır (Topçu, 2009). Ülkemizde son yıllarda çocuk istismarı konusunda bilinç ve duyarlılık artmış, birçok hastanede "Çocuk Koruma Birimleri” kurulmuştur. Bu birimlerin içinde çocuk sağlığı, çocuk psikiyatrisi, çocuk cerrahisi, adli tıp, beyin cerrahisi, ortopedi, göz gibi tıbbi alanlar dışında, sosyal hizmet uzmanı ve psikolog da yer almaktadır (Koç ve diğerleri, 2012).

Cinsel istismar önleme çalışmalarında çocuğun kendini fiziksel ve duygusal tehlikelerden koruyabilmesi gerekmektedir. Fiziksel tehlikeler; aile içi şiddeti, cinsel istismarı, akran baskısını ve akran ilişkilerini kapsamaktadır. Duygusal tehlikeler; sır saklama, mağdur edilme ve zayıf iletişim becerilerinden dolayı kendini ortaya koyamama şeklinde olabilmektedir. Cinsel istismarda bu duygusal tehlikelerin her biri etkili olabilir; çocuk utanç duyduğu için istismarı sır olarak saklayabilir, mağdur edilebilir ve iletişim becerilerinden dolayı kendini ifade etme konusunda sorun yaşayabilir (Geldard ve Geldard, çev., 2013). Sonuç olarak kendini güvende hisseden çocukların yaşadıklarını ifade etme konusunda daha az sıkıntı yaşadıkları düşünülmektedir.

Çocukların güvende olmaları ve güvenli hissetmeleri için, toplumda hangi sınırların normal, arzu edilir ve kabul edilebilir olduğunu açıkça anlamaya ihtiyaçları vardır. Bu sınırlara ilişkin beklenti ve davranışları anlamaya da ihtiyaç duyarlar. Benzer şekilde çocuklara yardım ederken, terapistin de gelişimsel, ailesel, toplumsal ve kültürel sınırları göz önünde bulundurması gerekmektedir (Geldard ve Geldard, çev., 2013). Gelişimsel olarak ele alındığında, çocuğun gelişimsel sınırları yaşı ilerledikçe sürekli gelişmekte ve değişmektedir. Örneğin, bebekken kucağa alınmaktan hoşlanan bir çocuk, yaşı ilerledikçe yabancıların kendisine dokunmasından ve kendisini kucaklamasından hoşlanmayacaktır. Ailesel olarak bakıldığında, çocuğun aile sınırları iki uç arasında değişken bir yapıya sahip olabilir. Aile ya çok katı ya da iç içe geçmiş olabilir. Toplumsal sınırlar ise, toplumda hangi davranışın uygun hangisinin uygun olmayacağıyla ilişkili tutum ve inançları kapsamaktadır. Örneğin, bir çocuğun bir yetişkinle cinsel ilişki yaşaması yasalarla yasaklanmıştır. Aynı şekilde kültürel sınırlar, çocuğun içinde bulunduğu kültüre ve dine göre neyin uygun olup neyin olmayacağıyla ilişkilidir (Geldard ve Geldard, çev., 2013). Örneğin, Türkiye'de hala bazı ebeveynler tarafından dayağın bir eğitim aracı olarak kabul edilmesi, dayağın atasözlerinde yer alıyor olması (Dayak cennetten çıkmadır) ülkemizde fiziksel istismarın sosyokültürel etkilerinden biri olarak görülebilmektedir (Ayvaz ve Aksoy, 2004; Topbaş, 2004). Erdoğan ve diğerlerine (2011) göre Türkiye'deki sosyokültürel yapının diğer toplumlara oranla daha geleneksel olması ve dini sebeplerin etkisiyle cinsel yaşantının sınırlı olması ve küçük yaşta evliliğin kabul edilebilir olması cinsel istismar olgularında etkili olabilmektedir. 
Özetle, önleme çalışmalarında çocukları cinsel istismardan koruyabilmek için onlara "kendine iyi bak ve kendini zararlı ve olası tehlikelerden koru" mesajını vermek gerekmektedir. Çocuğun uygun cevap verebilmesi için uygun sınırları anlaması, kendini fiziksel ve duygusal tehlikelerden koruyabilmesi gerekmektedir Çocuklara bu mesajın verilebilmesi için çeşitli çalışma kâğıtlarından ve psikoeğitim programlarından yararlanılabilir (Geldard ve Geldard, çev., 2013). Ülkemizde Karabağlar Kaymakamlığı'nın Çocuk İhmal ve İstismarını Önleme Projesi (Karabağlar Kaymakamlığı) ve Avrupa Konseyinin Çocuğa Karşı Cinsel Şiddeti Durdurmak İçin Beş’te Bir Kampanyası (Çocukhaklarizleme. org) gibi çalışmalar yürütülmekte olsa da ilgili alanyazında yeteri kadar çalışma olmadığı görülmektedir. Bu derlemede bahsedilen çalışma kâğıtları ve psikoeğitim programlarının Türk kültürüne adapte edilmesinin cinsel istismarı önleme açısından oldukça önemli olduğu düşünülmektedir.

\section{Çalışma Kâğıtlarının Kullanımı}

Geldard ve Geldard (çev. 2013) cinsel istismar konusunda çocukları bilgilendirmek, uygun olan ve olmayan davranışları onlara göstermek amacıyla birtakım çalışma kâğıtları önermektedir. Cinsel istismar konusunda çocukların uygun sınırları öğrenmeleri oldukça önemlidir. Bu grupta önerilen üç adet çalışma kâğıdı yer almaktadır. Bu çalışma kâğıtları ve işlevleri kısaca özetlenecektir.

\section{Yaşlar ve Dönemler}

Bu çalışma kâğıdı üç farklı yaştaki çocuğa sorulan üç farklı senaryoyu kapsamaktadır. Bu çalışma kâğıdında verilen kararların uygunluğunun farklı yaş dönemlerine göre değişebileceği vurgulanmaktadır. Çocuklardan çalışma kâğıdındaki çocuğun verebileceği en uygun cevabı bulmaları istenmektedir (Geldard ve Geldard, çev., 2013). Örneğin, “4 yaşındaki Ege’ye kapıyı yabancı biri çaldığında ne yapması gerektiği konusunda doğru kararı verebilmesi için yardım et.” sorusu sorularak çocuğa üç seçenek sunulmaktadır: "gülümse ve yabancıyı içeriye davet et”, "kapıyı aç ve sonra gidip bir yetişkine haber ver", "kapıyı hızla çarparak kapat ve kaç" (Geldard ve Geldard, çev., 2013). Bu senaryoda küçük yaş grubundaki bir çocuk kapıyı kilitlemeyi ve anne babasını beklemeyi daha uygun görürken; bir ergen kendisini koruma altına alarak o yabancının ne için geldiğini sorabilir.

\section{Benim Alanım Özel Alanım}

Farklı yaşlardaki çocuklar için aile ortamındaki uygun kişisel sınırlar değişmektedir. Bu çalışma kâğıdı da çocuğu bu sınırların ne olduğunu düşünmeye davet etmektedir. Çalışma kâğıdında "Fatma 7 yaşında. Dayısı evlerine her geldiğinde onunla birlikte duş almasına izin vermeli." gibi kurgusal cümleler yer almakta ve çocuktan bu cümleleri “doğru” ve "yanlış” olmak üzere cevaplaması istenmektedir. (Geldard ve Geldard, çev., 2013).

\section{Gökkuşağı Yolu}

Çocuklar için toplumsal sınırları keşfe yönelik hazırlanan bu çalışma kâğıdı, onların toplum içinde temasta bulunabilecekleri çeşitli insanlara verecekleri uygun tepkileri düşündürmeye yöneliktir. Çalışma kâğıdının üst kısmında 7 kutucuk yer almaktadır. Çocuğa çalışma kâğıdındaki çocuğun onunla aynı yaşta olduğu, dışarıya çıkacağı ve dışarıda birtakım insanlarla karşılaşacağı söylenmektedir. Çalışma kâğıdındaki çocuk bu insanlara selam verecektir. Nasıl selamlaşması konusunda çocuktan düşünmesi ve düşündüklerine göre gökkuşağının renkleriyle üst kısımdaki 7 kutucuğu boyaması istenmektedir (Geldard ve Geldard, çev., 2013). 
Sonuç olarak çalışma kağıtları terapist için çocuğun çeşitli davranış örüntülerine ve düşüncelerine odaklanma ve bunların ortaya çıkmasını sağlama açısından faydalı olabilmektedir. Terapist çalışma kâğıtları sayesinde çocuğun doğru ve yanlışlarını görerek bu çerçevede bir tedavi programı oluşturabilmektedir. Kullanılan çalışma kağıtları çocuklara uygun durumlarda hangi becerileri nasıl kullanacaklarını öğretmektedir (Geldard ve Geldard, çev., 2013).

\section{Psiko-eğitim Programları}

Cinsel istismarı önleme çalışmalarında çalışma kâğıtları kullanımının yanında bazı psiko-eğitim programları da tavsiye edilmektedir. Eroğul ve Hasırcı'ya göre (2013) ülkemizde düzenli uygulamalarına başlanmasa da Amerika Birleşik Devletleri ve Kanada gibi gelişmiş ülkelerde düzenli olarak kullanılan, önleme yöntemlerinden biri de bireylerin küçük yaşlardan itibaren cinsel istismardan korunabilmeleri için ilgili "kişisel güvenlik" ya da "iyi dokunuş kötü dokunuş" gibi farklı adlar altında okul temelli beceri eğitimi programlarının uygulanmasıdır. Bu programlarda öncelikle çocuğun iyi dokunuş ve kötü dokunuşa yönelik farkındalığı ölçülmektedir. Eroğul ve Hasırcı (2013) yaptıkları çalışmada orijinali Church, Forehand, Brown ve Holmes (1988) tarafından geliştirilen ve ilköğretim birinci kademedeki çocukların cinsel istismarla ilgili bilgi düzeylerini ölçmeyi amaçlayan İyi Dokunuş Kötü Dokunuş Ölçme aracının Türkçe’ye uyarlama, geçerlik ve güvenirlik çalışmalarını yapmışlardır. Bu araç, 10 maddeden oluşmakta ve maddeler, çocukların iyi ve kötü dokunuş arasındaki ayrımı yapıp yapamadığını, cinsel istismarla başa çıkma becerilerini bilip bilmediğini ve cinsel istismardan korunma becerilerinin çocuk tarafından kullanılıp kullanılmadığını belirlemeyi amaçlamaktadır. Ölçeğin puanlaması 0-1 şeklinde olup her soru için çocuğun cevaplaması gereken “doğru”, "yanlış" ve "bilmiyorum” tarzında 3 seçenek bulunmaktadır. Çocuk doğru cevap verdiği her soru için 1, yanlış ve bilmiyorum cevaplarını verdiği her soru için 0 puan almaktadır. Testten alınabilecek en yüksek puan 10, en düşük puan 0'dır. Yüksek puan, çocuğun cinsel istismardan korunma konusunda daha fazla bilgiye sahip olduğunu göstermektedir. Eroğul ve Hasırcı'nın (2013) yaptıkları çalışmada ilköğretim 4. Sınıf öğrencilerine yönelik verilen cinsel istismarı önleme programının deney grubunda etkili olduğu ve bu olumlu değişimin sekiz hafta sonrasında da devam ettiği bulunmuştur.

\section{Tartışma}

Bu derlemenin amacı, çocuk istismarı ve ihmali hakkında genel bir bilgi vermek, istismar türlerinden cinsel istismara yoğunlaşarak cinsel istismara uğramış çocuklara uygulanacak terapötik yöntemleri özetlemektir. Çocukluk çağı cinsel istismarı yaygın olarak görülen bir sorun olmakla birlikte, çocuklar üzerinde ileriye dönük hasarlar yaratabilir. Hasarın önlenebilmesi adına erken dönemde tespit ve müdahalesi oldukça önem taşımaktadır. Anne babalara cinsel istismar kavramının içeriği anlatılırken, çocuklara da özellikle bilgi verilmelidir.

Cinsel istismar konusunda pek çok yöntem kullanılsa da bu derlemede daha çok oyun terapisi ve oyun temelli kullanımlar üzerinde durulmuştur. Reyes ve Asbrand (2005) de oyun terapisi kullanmış ve çocukların istismarla baş etmesinde etkili sonuçlara ulaşmışlardır.

Yurt dışında hayvan destekli terapilerin kullanıldığı (Parish-Plass, 2008), kitap ve öykü kullanımının etkili olduğu (Herman, 1997), kum havuzu kullanımının çocuklar hakkında ayrıntılı bilgi sağladığı (Zinni, 1997) görülmektedir.

Cinsel istismara karşı koruyucu önlem olması açısından son yıllarda ülkemizde de özellikle hastanelerde disiplinler arası çeşitli birimler kurulmuş (Koç ve diğerleri, 2012) ve "İyi dokunuş, kötü 
dokunuş ölçme aracı" gibi cinsel istismarı önleme programlarında kullanılan ölçeklerin geçerlik güvenirliği yapılmıştır (Eroğul ve Hasırc1, 2013).

\section{Sonuç ve Öneriler}

Çocuk istismarı ve ihmalini önlemeye karşı pek çok yöntem kullanılsa da ülkemizde kullanılan tekniklerin sınırlı olduğu görülmektedir. Bu sebepten ülkemizde daha fazla oyun terapisi kullanımı yaygınlaştırılmalı, terapilerde etkili kullanılabilecek kum havuzu, kitap ve öykü kullanımı, hayvan destekli yaklaşımlar uyarlanmalıdır. Yurt dışında pek çok alanda uygulamasının olması, benzer çalışmaların ülkemizde de kullanılabileceğini düşündürmektedir.

Ülkemizde yapılabilecek bir diğer girişim de ailelere ve çocuklara verilen psiko-eğitimleri yaygınlaştırmak olabilir. Bu konuda "Çocuk Koruma Birimleri” tüm hastanelerde yaygınlaştırılmaya çalışılmalı, Milli Eğitim Bakanlığı'nın desteğiyle psiko-eğitim çalışmaları tüm okullarda ders olarak uygulanmalıdır. Ayrıca okullardaki rehber öğretmenler çalışma kâğıtlarından yararlanarak çocuk ve ailelere belirli aralıklarla seminerler vermelidir. Hastanelerde ve özel eğitim kurumlarında çocuklarla çalışan ilgili meslek gruplarına oyun terapisi eğitimi verilmeli, bu konuda ilgili kurumlarda yeterli fiziksel koşullar sağlanmalıdır.

Bu çalışma çocuk istismarı, özellikle cinsel istismar konusunda tedavi ve önlemeye yönelik detaylı bir derleme içerse de gelecek çalışmalar bu konuyu daha kapsamlı ele almalı, fiziksel, duygusal istismar ve ihmal konusunda yapılabileceklerden de bahsetmelidir. Bu derlemede Geldard ve Geldard'ın (çev., 2013) uygulamalarına ağırlık verilse de yapılacak çalışmalar alanyazındaki diğer yaklaşımları da ele almalı ve ülkemizde uygulanabilirliği konusuna yoğunlaşmalıdır. 


\section{Kaynaklar}

Acehan, S., Bilen, A., Ay, M.O., Gülen, M., Avc1, A., \& İçme, F. (2013). Çocuk istismarı ve ihmalinin değerlendirilmesi. Arşiv Kaynak Tarama Dergisi, 22(4), 591-614.

Ahioğlu, N. (2004). Yayınlara ve yargı kararlarına göre Türkiye'de çocuk istismarı. Ĕ̌̆itim Bilimleri ve Uygulama, 3(6), 277- 286.

Al- Qaisy, L.M. (2007). Impacts of physical and psychological abuse of children on family demographic variables. Journal of Science, 3(4), 232-236.

Axline, V.M. (1981). Play Therapy. NewYork: Ballantine Books.

Avcı, A., ve Tahiroğlu, A. Y. (2006). Cinsel istismar. İçinde Çocuk ve ergen ruh să̆lı̆̆l ve hastalıklarl. (ss. 721-726). Ankara.

Ayvaz, M., ve Aksoy, C.M. (2004). Çocuk istismarı ve ihmali: Ortopedik yönleri. Hacettepe Tıp Dergisi, 35, 27-33.

Bahar, G., Savaş, H.A., ve Bahar, A. (2009). Çocuk istismarı ve ihmali: Bir gözden geçirme. Fırat Sağllk Hizmetleri Dergisi, 4(12), 51-65.

Ballarini, G. (2003). Pet therapy. Acta Bio Medica, 74, 97-100.

Bulut, S. (2008). Erken çocukluk dönemi cinsel istismarının psikodinamik oyun terapisiyle teşhisi ve tedavisi. Türk Psikolojik Danışma ve Rehberlik Dergisi, 3(29), 131-144.

Centers for Disease Control and Prevention. (2014). Understanding child maltreatment. http://www.cdc.gov/violenceprevention/pdf/cm-factsheet-a.pdf adresinden elde edildi.

Çocukhaklariizleme.org. http://www.5te1.cocukhaklariizleme.org/ adresinden elde edildi.

Ekşi, A. (1999). Ben Hasta Değilim. İstanbul: Nobel Tıp Kitapevi.

Erdoğan, A., Tufan, E., Karaman, M. G., Atabek, M. S., Koparan, C., Özdemir, E., ve diğerleri. (2011). Türkiye'nin dört farklı bölgesinde çocuk ve ergenlere cinsel tacizde bulunan kişilerin karakteristik özellikleri. Anadolu Psikiyatri Dergisi, 12, 55-61.

Eroğul, A.R.Ç., ve Hasırcı, Ö.K. (2013). İlköğretim birinci kademe öğrencilerine yönelik geliştirilen cinsel istismarı önleme psiko-eğitim programının etkililiğinin sınanması. Kuram ve Uygulamada Eğitim Bilimleri, 13(2), 719-729.

Geldard, K., ve Geldard, D. (2013). Çocuk Psikoterapisi: Giriş Niteliğinde Uygulamalı Bir Rehber. (G. Erden; Ç. Kudiaki, İ. Dikmeer,. Çev. Ed.). Ankara: Türk Psikologlar Derneği Yayınları (2008).

Glaser, D. (2002). Emotional abuse and neglect (psychological maltreatment): A conceptual framework. Child Abuse and Neglect, 26, 697-714.

Grubbs, G. A. (1995). A comparative analysis of a sandplay process of sexualy abused and nonclinical children. The Arts in Psychotherapy, 22(5), 429-446.

Güner, Ş.İ., Güner, S., ve Şahan, M. H. (2010). Çocuklarda sosyal ve medikal bir problem: istismar. Van Tip Dergisi, 17(3), 108-113.

Herman, L. (1997). Goodenough fairy tales for resolving sexual abuse trauma. The Arts in Psychotherapy, 24(5), 439-445.

Hildyard, K. L., ve Wolfe, D. A. (2002). Child neglect: Developmental issues and outcomes. Child Abuse \& Neglect, 26, 679 -695.

Homeyer, L.E., ve Landreth, G.L. (1998). Play therapy behaviors of sexually abused children. International Journal of Play Therapy, 7(1), 49-71.

İmren, S.G., Ayaz, A.B., Yusufoğlu, C., ve Arman, R. A. (2013). Cinsel istismara uğrayan çocuk ve ergenlerde klinik özellikler ve intihar girişimi ile ilişkili risk etmenleri. Marmara Medical Journal, 26, 11-16. 
Jaberghaderi, N., Greenwald, R., Rubin, A., Zand, S.O., ve Dolatabadi, S. (2004). A comparison of CBT and EMDR for sexually- abused Iranian girls. Clinical Psychology and Psychotherapy, 11, 358- 368.

Johnson, C.F. (2003). Abuse and neglect of children. Behrman, R.E., Kliegman, R.M., Jenson, H.B. (Ed.) içinde, Nelson textbook of pediatrics(17. basım) (ss. 122-132). Philadelphia: WB Saunders.

Kara, B., Biçer, Ü., ve Gökalp, A.S. (2004). Çocuk istismarı. Çocuk Sağlı̆̆l ve Hastalıkları Dergisi, 47, 140151.

Karabağlar Kaymakamlığı. http://www.karabaglar.gov.tr/ortak_icerik/karabaglar/\%C3\%87ocuk\%20 $\% \mathrm{C} 4 \% \mathrm{~B} 0 \mathrm{hmal} \% 20 \mathrm{ve} \% 20 \% \mathrm{C} 4 \% \mathrm{~B} 0$ stismar\%C4\%B1n\%C4\%B1\%20\%C3\%96nleme\%20Projesi.pdf adresinden elde edildi.

Katz, C., Barnetz, Z., ve Hershkowitz, I. (2014). The effect of drawing on children's experiences of investigations following alleged child abuse. Child Abuse \& Neglect, 38, 858-867.

Keser, N., Odabaş, E., ve Elibüyük, S. (2010). Ana- babaların çocuk istismarı ve ihmali konusunda bilgi düzeylerinin incelenmesi. Türkiye Çocuk Hastalıkları Dergisi, 4(3), 150-157.

Koç, F., Aksit, S., Tomba, A., Aydın, C., Koturoğlu, G., Çetin, S.K., ve diğerleri. (2012). Çocuk istismarı ve ihmali olgularımızın demografik ve klinik özellikleri: Ege Üniversitesi Çocuk Koruma Birimi’nin bir yıllık deneyimi. Türk Pediatri Arşivi, 47, 119- 124.

Mullen, P.E., Martin, J. L., Anderson, J. C., Romans, S. E., ve Herbison, G. P. (1996). The long term impact of the physical, emotional, and sexual abuse of children: A community study. Child Abuse \&Neglect, 20(1), 7-21.

Ovayolu, N., Uçan, Ö., ve Serindağ, S. (2007). Çocuklarda cinsel istismar ve etkileri. Fırat Sağlık Hizmetleri Dergisi, 2(4), 13-22.

Özen, Y.(2015). Çocuklarda Bilişsel Davranış Psikolojisi: Bize Yeni Bir Ben Lazım. Ankara: Yason Yayınevi.

Pala, B., Ünalacak, M., ve Ünlüoğlu, İ. (2011). Child maltreatment: Abuse and neglect. Dicle Tip Dergisi, $38(1), 121-127$.

Paolucci, E.O., Genius, M.L., ve Violato, C. (2001). A meta-analysis of the published research on the effects of child sexual abuse. The Journal of Psychology, 135(1), 17-36. doi: 10.1080/00223980109603677

Parish-Plass, N. (2008). Animal-Assisted therapy with children suffering from insecure attachment due to abuse and neglect: a method to lower the risk of intergenerational transmission of abuse? Clinical Child Psychology and Psychiatry, 13(1), 7-30. doi: 10.1177/1359104507086338

Reichert, E. (1998). Individual counseling for sexually abused children: A role for animals and storytelling. Child and Adolescent Social Work Journal, 15(3), 177- 185.

Reyes, C.J., ve Asbrand, J.P. (2005). A longitudinal study assessing trauma symptoms in sexually abused children engaged in play therapy. International Journal of Play Therapy, 14(2), 25- 47.

Sanders, M.J., ve Brown, S.R. (2007). Çocuk istismarı. Steiner, H. ve Yalom, I.D. (Ed.) içinde, Okul öncesi çocuklarının terapisi. (Ş.Ç. Yeşilmen, Çev.). (ss. 203-234). İstanbul: Prestij Yayınları (1997).

Sattler, J. M. (1998). Clinical and forensic interviewing of children and families: Guidelines for the mental health education, pediatric, and child maltreatment fields. San Diego CA: Jerome M. Sattler Publisher.

Sorbo, M. F., Grimstad, H., Bjorngaard, J.H., Schei, B., ve Lukasse, M. (2013). Prevalence of sexual, physical and emotional abuse in the Norwegian mother and child cohort study. BMC Public Health, 13, 186.

Taner, Y., ve Gökler, B. (2004). Çocuk istismarı ve ihmali: Psikiyatrik yönleri. Hacettepe Tıp Dergisi, 35, 82-86.

Topbaş, M. (2004). İnsanlığın büyük bir ayıbı: Çocuk istismarı. TSK Koruyucu Hekimlik Bülteni, 3(4), 7680. 
Topçu, S. (2009). Cinsel istismar. Ankara: Phoenix Yayınevi.

World Health Organization (2002). World Report Violence and Health http://whqlibdoc.who.int/ publications/2002/9241545615_eng.pdf adresinden elde edildi.

Yaşar, Z.F., ve Akduman, G.G. (2007). Çocuk ihmali-istismarı ve adli diş hekimliği. TSK Коrиyисu Hekimlik Bülteni, 6(5), 389-394.

Yılmaz, G., İșiten, N., Ertan, Ü., ve Öner, A. (2003). "Bir çocuk istismarı vakası”. Çocuk Sağll̆̆g ve Hastallkları Dergisi, 46, 295-298.

Zinni, R.V. (1997). Differential aspects of sandplay with 10- and 11- year old children. Child Abuse \& Neglect, 21(7), 657-668. 